\section{Vargas Llosa e a cultura}

(LLOSA, Mario Vargas. A civilização do espetáculo. Rio de Janeiro: Objetiva, 2012.)

Andreia Santos Gonçalves*

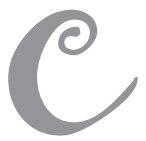

om uma linguagem clara, objetiva e contemporânea o escritor peruano Mario Vargas Llosa (1936), vencedor do Prêmio Nobel de Literatura em 2010, jornalista, dramaturgo e crítico literário, faz uma inovadora reflexão sobre o conceito de cultura e o atual estágio de civilização da sociedade em seu livro publicado em 2012: A civilização do espetáculo.

Mas, afinal o que vem a ser cultura? Esse é um conceito mutável ao longo do tempo? Como é sua construção? Apesar de ser um tema vanguardista e muito explorado por outros autores, nesta obra o termo cultura é apresentado levando em consideração o momento pós-moderno e globalizado que envolve a pré-construção dos conhecimentos adquiridos pelo homem ao longo da história, por meio da crítica à sociedade do espetáculo.

O desenvolvimento cultural de um povo é representando por sua civilização e corresponde também às transformações nas técnicas dominadas, nas relações sociais estabelecidas, nos fatores econômicos e de criação artística, acumuladas ao longo do tempo. Todo esse progresso e evolução nos diversos setores da vida social culminaram, de acordo com o autor, em uma civilização efêmera que, muitas vezes, pouco contribui para o avanço intelectual, sociocultural e econômico, interferindo sobremaneira na identidade cultural das sociedades modernas.

Estaria a cultura passando por uma metamorfose, atravessando uma crise profunda, entrando em decadência ou se renovando? Esses questionamentos são abordados pelo autor ao longo de sua obra por meio de temas como religião, política, educação, erotismo, arte e literatura revelando, em alguns momentos, certo inconformismo com a ligação entre a cultura e o entretenimento, bem como da efemeridade na forma de adquirir conhecimentos (qualidade e não quantidade).

As civilizações tendem a desenvolver culturas complexas sendo essas transmitidas por meio da família, da escola, da Igreja, do Estado, do grupo no qual se está inserido e quando essas instituições deixam de funcionar de maneira adequada,
Recebido: 17.03.14

Aprovado: 05.09.14

* Doutora em

sociologia pelo PPGSOL/UnB.

<andreia.goncalves@ inep.gov.br>. 
ou esperada, o resultado pode ser a "deterioração da cultura" e a interferência na civilidade de um povo.

Para Llosa, A civilização do espetáculo está cingida ao âmbito da cultura, não entendida como mero epifenômeno da vida econômica e social, mas como realidade autônoma, feita de ideias, valores estéticos e éticos, de obras artísticas e literárias que interagem com o restante da vida social e que muitas vezes são a fonte, e não o reflexo, dos fenômenos sociais, econômicos, políticos e até religiosos.

A cultura e o processo de civilização apresentados pelo autor se constroem hoje também por meio das redes sociais, da internet, da televisão, do cinema e do jornalismo sensacionalista, chegando a todas as camadas sociais de forma acessível, sem exigir, para sua fruição, formação intelectual especializada de nenhum tipo como em um movimento de contracultura.

Nesse sentido, a diferença essencial entre a cultura do passado e essa nova, apresentada por Llosa, é que aquela pretendia transcender o tempo presente, durar e continuar viva nas gerações futuras; essa é construída para ser consumida no momento e desaparecer em seguida (absorvido versus anulado). Essa nova cultura, portanto, nasce com o predomínio da imagem e do som sobre a palavra/as ideias sendo essenciais a produção industrial maciça e o sucesso comercial, já que a distinção entre preço e valor se apagou, ambos agora são um só, tendo o primeiro absorvido e anulado o segundo.

Isso implica, segundo Llosa, no desaparecimento do velho conceito de valor e no estabelecimento de uma civilização na qual o primeiro lugar na tabela de valores vigentes é ocupado pelo entretenimento: divertir-se e escapar do tédio tornaram-se paixão universal.

Mas, é errado divertir-se e buscar distração? Não. O que Llosa chama a atenção é para a banalização da cultura, generalização da frivolidade e, no campo da informação, a proliferação do jornalismo de escândalo e da bisbilhotice. Transformar em valor supremo essa propensão natural a divertir-se pode ter consequências inesperadas a influência decisiva sobre os gostos, as sensibilidades, a imaginação e os costumes da publicidade que, muitas vezes, não está isenta na formação de opiniões.

Na civilização do espetáculo, a intelectualidade só se interessará se estiver aliada à moda e, com isso, a produção de novos criadores e intelectuais estará em risco com a propensão ao sofisma e ao artifício intelectual. Essa civilização do espetáculo é 
cruel, ou seja, ela apresenta pessoas sem memória, que vivem presas à novidade, não importa qual seja, e por isso também sem verdadeira consciência.

\begin{abstract}
Agora somos todos cultos de alguma maneira, embora nunca tenhamos lido um livro, nem visitado uma exposição de pintura, assistindo a um concerto, adquirido algumas noções básicas dos conhecimentos humanísticos, científicos e tecnológicos do mundo que vivemos.
\end{abstract}

A cultura, então, deveria preencher esse vazio intelectual que outrora era ocupado pelas diversas áreas do saber. Mas, segundo o autor, é impossível que isso ocorra pois, a cultura, retirando-se dessa responsabilidade, orienta-se resolutamente para a facilidade, esquiva-se dos problemas mais urgentes e transforma-se em mero entretenimento, o ópio do povo, esquecendo-se da expressão crítica.

Assim, essa obra busca uma reflexão principalmente sobre a crítica que anteriormente desempenhava um papel fundamental no mundo da cultura por assessorar as pessoas na difícil tarefa de julgar o que ouviam, viam e liam, já que parar o autor, hoje há uma espécie em extinção da crítica que significa transformá-la em diversão e espetáculo (massificação).

Ao se falar de crítica, deve-se ter um olhar voltado não apenas para a superficialidade dos conhecimentos adquiridos hoje, mas para os avanços proporcionados pela tecnologia para alcançar esses conhecimentos chamados de superficiais nessa obra. A internet, por exemplo, não tornou supérflua a literatura, o cinema, a música ou os conhecimentos como um todo e sim tornou tudo isso acessível a qualquer pessoa em qualquer lugar.

A revolução da informação e sua acessibilidade não podem descaracterizar a escola ou a formação de intelectuais e sim contribuir para a constituição de uma civilização que exija mais da formação de seus componentes para ser assim um espetáculo na concepção da palavra. Onde estão os novos intelectuais? Estariam eles optando pelo silencio a assumir a tarefa de estruturar pensamentos? Ou nem existiriam mais?

Considerar essa postura - talvez apática e omissa - é revelar um descompromisso dessas pessoas e uma maior abertura para o chamado banal pelo autor. Ressalta-se que, não há perda de espaços e sim renovação de espaços, promovido pelo período de "democratização" universal da cultura e de globalização do conhecimento na contemporaneidade, mas sem empobrecê-los ou torná-los superficiais.

Que essa resenha não tire o prazer do leitor em apreciar esse envolvente livro, fazendo-o cair na tal civilização do espetáculo na qual tudo e nada é cultura. Expe- 
rimente, reflita, pense, sonhe, imagine, revisite suas certezas, convicções, teorias, crenças e principalmente seus valores.

DOI: 10.1590/S0102-699220150002000014 